\title{
Flexible synthesis of anthracycline aglycone mimics via domino carbopalladation reactions
}

\author{
Markus Leibeling and Daniel B. Werz
}

\section{Full Research Paper}

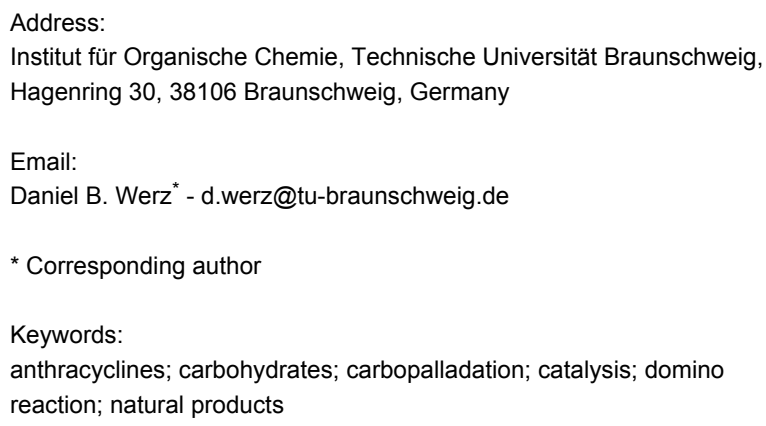

Beilstein J. Org. Chem. 2013, 9, 2194-2201.

doi:10.3762/bjoc. 9.258

Received: 28 August 2013

Accepted: 08 October 2013

Published: 24 October 2013

This article is part of the Thematic Series "Natural products in synthesis and biosynthesis".

Guest Editor: J. S. Dickschat

(C) 2013 Leibeling and Werz; licensee Beilstein-Institut.

License and terms: see end of document.

\begin{abstract}
A synthesis of anthracycline aglycone derivatives is described. The key step utilizes a powerful domino carbopalladation approach and subsequent ring closure. During this process two of the four rings of the anthracycline scaffold are formed. Differently substituted carbohydrates and dialkyne chains serve as versatile and simple starting materials for the reaction sequence. Diverse building blocks lead to a variety of different products and a broad range of structural diversity.
\end{abstract}

\section{Introduction}

Anthracyclines are a widespread class of natural products which belong to the group of aromatic polyketides [1]. Most of them have been isolated from bacteria of the order Streptomycetales. The group of Brockmann, who first found anthracyclines in 1963, described them as red to orange dyes [2]. Their structure elucidation revealed a linear fourfold annulated ring system including two benzene units (A-ring and C-ring). The substitution pattern of the D-ring bares most of the functionalities, i.e., a secondary and a tertiary alcohol, the former of which is commonly glycosylated with 2,6-dideoxy sugars (Figure 1) [3]. These carbohydrates are of highest importance for the biological activity of anthracyclines and bind to the minor groove of double-stranded DNA [4,5]. While the mode of action of anthracyclines is still not fully understood, it is widely accepted that these chemotherapeutic agents form a ternary complex with double-stranded DNA and topoisomerase II thereby leading to DNA damage and cell death [6,7]. They are used to treat different types of diseases such as leukemias, lymphomas, breast, uterine, ovarian and lung cancers [8].

Thus, many research groups faced the challenge of investigating suitable pathways for the synthesis of diverse anthracycline natural products and mimics thereof. Because of the inherent lack of efficient synthetic approaches to anthracyclines 
<smiles>[R]CC(=O)[C@]1(O)Cc2c(O)c3c(c(O)c2[C@@H]([R9])C1)C(=O)c1c([R])cccc1C3=O</smiles>

1

$\mathrm{R}^{3}$ :

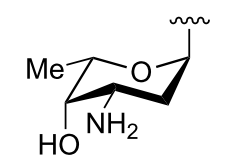

Daunomycin (a): $\quad \mathrm{R}^{1}=\mathrm{OMe}, \mathrm{R}^{2}=\mathrm{H}$

Doxorubicin (b): $\quad \mathrm{R}^{1}=\mathrm{OMe}, \mathrm{R}^{2}=\mathrm{OH}$

Idarubicin (c): $\quad \mathrm{R}^{1}=\mathrm{H}, \mathrm{R}^{2}=\mathrm{H}$

Figure 1: Several natural occurring anthracycline antibiotics.

many industrial approaches still rely on the use of recombinant microorganisms with a mutated gene of the anthracycline metabolism [9].

Different convenient synthetic transformations involve the application of a Diels-Alder reaction as key step for the aspired synthesis [10-13]. A classical synthesis was published in 1988 by Hansen where a silyl-substituted diene $\mathbf{3}$ was used for the [4 + 2]-cycloaddition (Scheme 1) [14]. Starting from bisquinone 4 the annulated ring system 5 is obtained in a 1:1 mixture of cisendo regioisomers. Subsequent aromatization of the C-ring and several additional steps generated the daunomycin aglycon $\mathbf{6}$ and the corresponding isodaunomycin aglycone (dependent on the regioisomers) in a total of 16 steps.

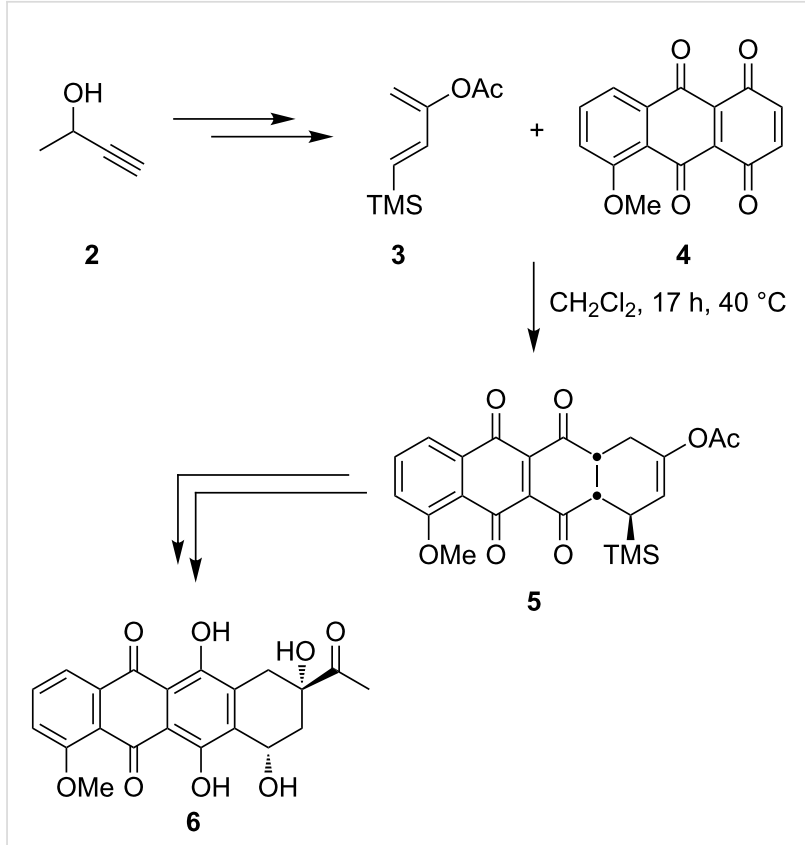

Scheme 1: Total synthesis of daunomycinone 6 according to Hansen.

In 2003, Saá published a concise route to anthraquinone derivatives by using an intramolecular dehydro-Diels-Alder reaction of an aryldiacetylene system (Scheme 2) [15]. Compound 7 reacts at high temperature in a mixture consisting of toluene and triethylamine to an inseparable mixture of cyclized diol (52\%) and quinone 8 (36\%). Quantitative oxidation of the diol by $\mathrm{MnO}_{2}$ provided the desired tetracycle 8 in $88 \%$ overall yield (over two steps). Another approach to non-linear systems utilizes a cobalt-mediated intramolecular $[2+2+2]$-cycloaddition of a triyne system 9 leading to the fourfold annulated ring system $\mathbf{1 0}$ in only one step [16]. Late stage functionalization led to the anticipated structural motif in a few additional steps.<smiles>C#CC(O)c1ccccc1C(O)C#CC1=CCCCC1</smiles>

1) toluene/ $/ \mathrm{NEt}_{3}, 150{ }^{\circ} \mathrm{C}, 2 \mathrm{~h}$

2) $\mathrm{MnO}_{2}, \mathrm{CH}_{2} \mathrm{Cl}_{2}, 25^{\circ} \mathrm{C}$

$\underset{\mathrm{Et}_{2} \mathrm{O},-60^{\circ} \mathrm{C} \rightarrow 0{ }^{\circ} \mathrm{C}, 4 \mathrm{~h}}{\stackrel{\left[\mathrm{CpCo}\left(\mathrm{C}_{2} \mathrm{H}_{4}\right)_{2}\right](1.0 \text { equiv })}{\longrightarrow}}$<smiles>COc1cccc2cc3c4c(ccc3cc12)C[C@@H](C)CC4</smiles>

$10(93 \%)$ 


\section{Results and Discussion}

\section{Retrosynthetic strategy}

After having established several methods of domino carbopalladation reactions which employ dialkynyl-substituted bromoglycals [17-20] or bromoarenes [21], we envisioned to apply a similar procedure for the preparation of anthracycline derivatives. Therefore, the D-ring was exchanged for a pyranose, as described in our previous synthetic approaches for the syntheses of chromans, isochromans and biphenyls, respectively. These 2-bromoglycals 15 are well-known compounds and their synthesis was accomplished according to literature-known procedures $[17,18]$. The dialkyne unit provides both the A-ring and the information for the formation of the B and C-ring within the palladium-catalyzed domino transformation [22-27]. Such an approach should allow an easy differentiation between all four annulated cycles and their possible modification, whereupon the main focus was the preparation of several D-ring derivatives.

The anthraquinone moiety $\mathbf{1 1}$ should be formed within the last steps of the synthetic approach by benzylic oxidation of compound 12 (Scheme 3). The terminal silyl group and the silyl ether should be removed by using hydrolysis and fluoride-mediated desilylation, respectively. It was assumed that the multiple carbopalladation/cyclization sequence should give access to the fourfold-annulated ring system $\mathbf{1 3}$ in a single step. However, we knew that the domino process works much better in an intrathan in an intermolecular fashion [19]. Thus, we decided to employ a silyl ether moiety to connect both subunits $\mathbf{1 5}$ and $\mathbf{1 6}$. As the terminus of the other alkyne unit we also chose a silyl group. Depending on the kind of the silyl group a variety of further functionalization might be envisioned. Respective silyl- substituted diynes 16 can be traced back to phthalide (17). To differentiate between the insertion of two differently substituted silylacetylenes, the lactone $\mathbf{1 7}$ had to be first converted into a monoprotected diol for further transformations.

\section{Synthesis of dialkyne building blocks}

The choice of the right diyne is crucial for a successful synthesis of the target compound. Preliminary investigations had shown that both dialkynes with benzylic hydroxy functionalities and 1,2-bis(2-propynyl)benzene did not yield viable results in the domino reaction. The selective installation of only one silyl group at a dialkyne with two terminal acetylene moieties presented difficulties. Thus, we sought for a consecutive introduction of the corresponding silylacetylene functionalities. An appropriate starting material was selected to achieve a highly convergent and convenient synthetic strategy. We started our investigation with the reduction of commercially available phthalide (17) by $\mathrm{LiAlH}_{4}$ into dialcohol 18 in quantitative yield [28] (Scheme 4). The polar compound was easily converted into the mono-TBS-protected substrate by utilization of 1 equivalent of TBSCl [29]. Column chromatography afforded three fractions consisting of the starting material, the monoprotected and the diprotected product. The remaining alcohol moiety of compound 19 was converted into the respective iodide 20 by a Mukaiyama redox-condensation using elemental iodine, triphenylphosphine and imidazole [30]. The installation of a suitable leaving group sets the stage for the introduction of the first silylacetylene. Four different terminal alkynes 21 (a: $S i=$ TMS; b: $S i=\mathrm{SiMe}_{2} \mathrm{Ph}$; $\left.: S i=\mathrm{SiMe}_{2} \mathrm{Bn} ; \mathbf{d}: S i=\mathrm{Si}(\mathrm{iPr})_{2} \mathrm{H}\right)$ were employed. Best results with yields of over $80 \%$ were obtained by the use of acetylene $\mathbf{2 1 a}$, ethylmagnesium bromide, and

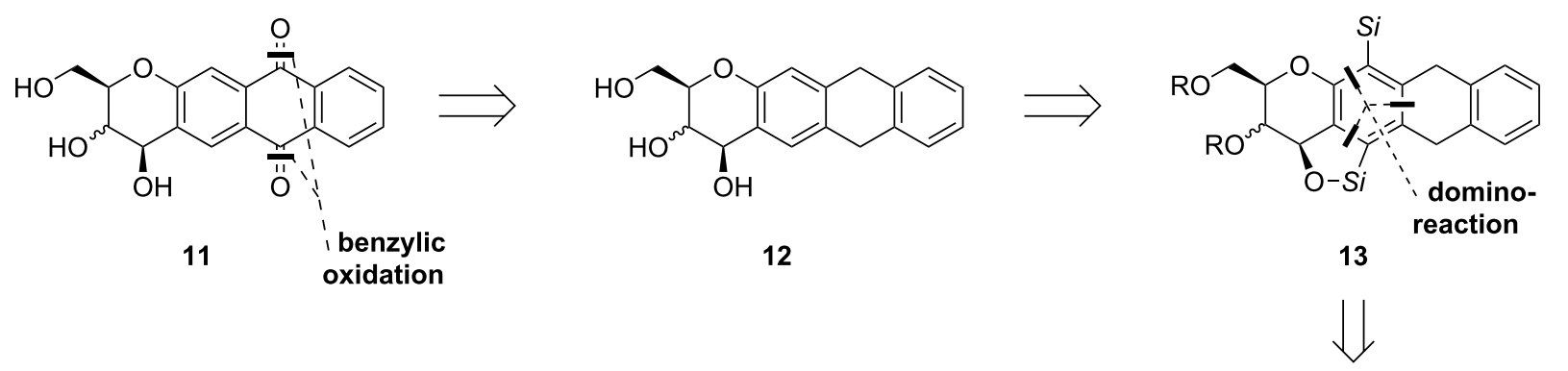

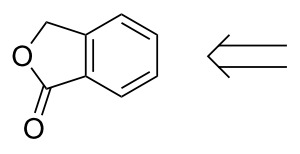

17<smiles>[Si]C#CCc1ccccc1CC#C[SiH3]</smiles>

16<smiles>[R]CC1OC=C(Br)C(O)C1[R9]</smiles>

15

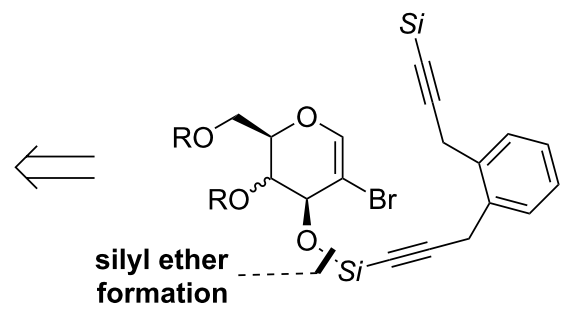

14 


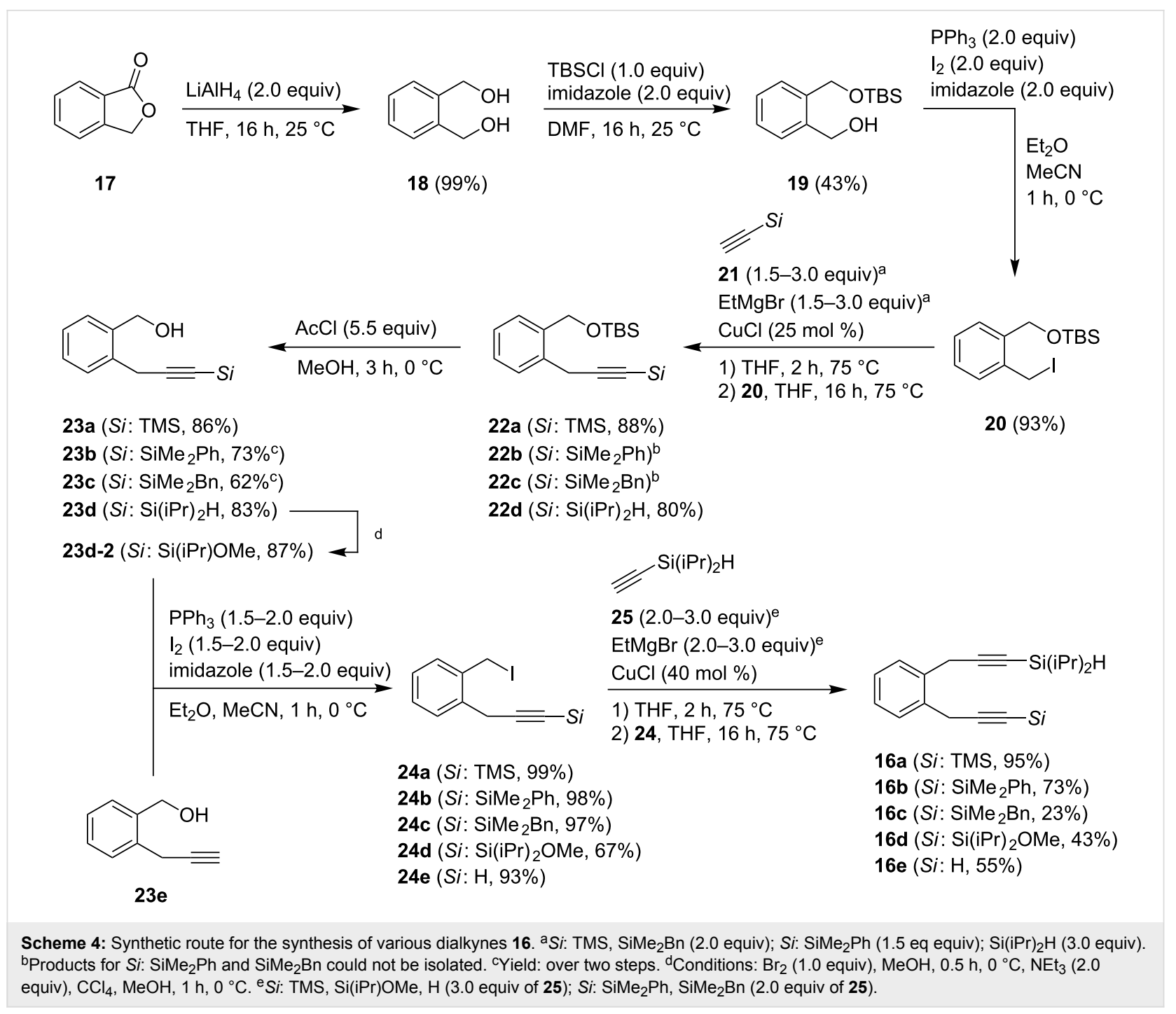

copper chloride in tetrahydrofuran for one hour at $75{ }^{\circ} \mathrm{C}$, successive addition of iodide $\mathbf{2 0}$ in THF at room temperature and additional $16 \mathrm{~h}$ under reflux [31]. Products $\mathbf{2 2 b}$ and 22c could not be isolated in pure form due to small impurities. The deprotection of the silyl ethers proceeded smoothly with high yields ranging from $62 \%$ to $86 \%$ over two steps [32]. Silane 23d was converted into the corresponding silyl bromide and trapped with methanol to install an electron-deficient substituent at the silane moiety $\mathbf{2 3 d - 2}$. The synthesis of $\mathbf{2 3 e}$ was accomplished according to a literature-known procedure starting from isochromanone and trimethylsilyl-diazomethane [33]. The initially formed alcohols $\mathbf{2 3}$ were again converted into the respective iodides $\mathbf{2 4}$ as described before and subsequently substituted with diisopropylsilylacetylene 25 [34] providing five different dialkynes $\mathbf{1 6}$, each of them with a terminal silyl substituent (or terminal hydrogen) at one side and a silane moiety at the other (Scheme 4). It is possible to access differently substituted dialkynes 16 by the silylation of 16e. This ap- proach was not considered because of the low tolerance of $\mathbf{1 6 e}$ against base and the expensive starting materials for the synthesis of 23e.

\section{Silyl ether formation and domino reaction}

The union between both building blocks proved to be more difficult than originally envisioned. During our previous studies of chromans and isochromans the implementation of ether linkages afforded good results. The synthesis of anthracycline derivatives requires a more labile connection to circumvent the formation of an additional cycle at the annulated ring system. Previous investigations revealed that silyl ether formations could be accomplished by the transformation of the silane into the corresponding silyl bromide by using NBS [35]. This highly reactive species should be easily trapped by the hydroxy functionality of the respective 2-bromoglycal. Therefore, we chose 15a and 16a as model substrates to explore suitable reaction conditions for the silyl ether formation. Table 1 reveals that of 
Table 1: Optimization study for the silyl ether formation.

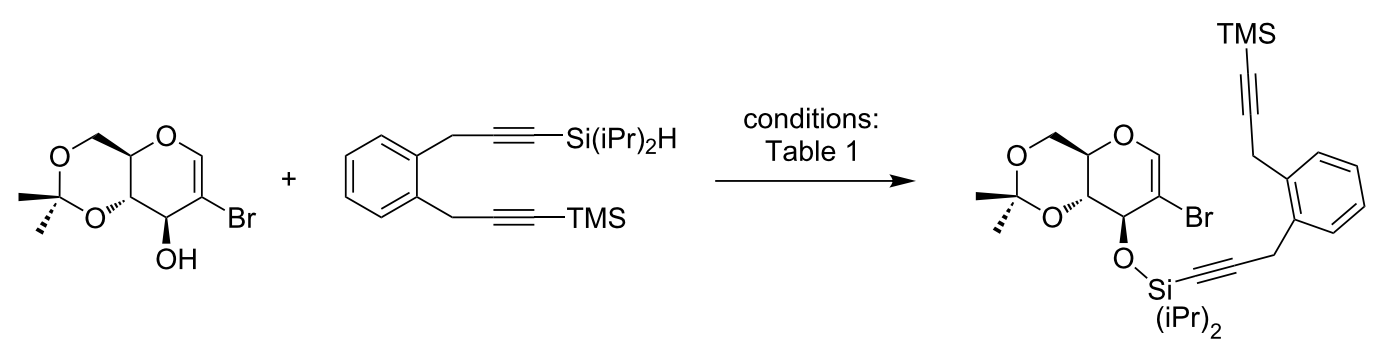

$15 a$

$16 a$

$14 a$

\begin{tabular}{|c|c|c|}
\hline entry & conditions $^{a}$ & yield [\%] \\
\hline 1 & 1) $15 a$ (1.1 equiv), NBS (1.1 equiv). 2) $16 \mathrm{a}$ (1.0 equiv), $\mathrm{NEt}_{3}$ (2.0 equiv), $\mathrm{CH}_{2} \mathrm{Cl}_{2}$ & 23 \\
\hline 2 & 1) $15 \mathrm{a}$ (1.1 equiv), $\mathrm{NCS}$ (1.1 equiv). 2) $\mathbf{1 6 a}$ (1.0 equiv), $\mathrm{NEt}_{3}$ (2.0 equiv), $\mathrm{CH}_{2} \mathrm{Cl}_{2}$ & 12 \\
\hline 3 & 1) $15 \mathrm{a}$ (1.1 equiv), $\mathrm{NIS}$ (1.1 equiv). 2) 16a (1.0 equiv), $\mathrm{NEt}_{3}$ (2.0 equiv), $\mathrm{CH}_{2} \mathrm{Cl}_{2}$ & - \\
\hline 4 & 1) $15 \mathrm{a}$ (1.1 equiv), $\mathrm{Br}_{2}$ (1.1 equiv). 2) $16 \mathrm{a}$ (1.0 equiv), $\mathrm{NEt}_{3}$ (2.0 equiv), $\mathrm{CH}_{2} \mathrm{Cl}_{2}$ & 27 \\
\hline 5 & 1) $15 \mathrm{a}$ (1.0 equiv), $\mathrm{Br}_{2}$ (1.1 equiv). 2) $\mathbf{1 6 a}$ (1.0 equiv), $\mathrm{NEt}_{3}$ (1.3 equiv), $\mathrm{Et}_{2} \mathrm{O}$ & $42^{b}$ \\
\hline 6 & 1) $15 \mathrm{a}$ (1.1 equiv), $\mathrm{Br}_{2}$ (1.1 equiv). 2) $16 \mathrm{a}$ (1.0 equiv), $\mathrm{NEt}_{3}$ (1.1 equiv), THF & - \\
\hline 7 & 1) $15 \mathrm{a}$ (1.3 equiv), $\mathrm{Br}_{2}$ (1.4 equiv). 2) $16 \mathrm{a}$ (1.0 equiv), $\mathrm{NEt}_{3}$ (1.3 equiv), $\mathrm{Et}_{2} \mathrm{O}$ & 36 \\
\hline 8 & 1) $15 \mathrm{a}$ (1.0 equiv), $\mathrm{Br}_{2}$ (1.0 equiv). 2) $16 \mathrm{a}$ (1.0 equiv), $\mathrm{NEt}_{3}$ (2.0 equiv), $\mathrm{Et}_{2} \mathrm{O}$ & 25 \\
\hline 9 & 1) $15 \mathrm{a}$ (1.0 equiv), $\mathrm{Br}_{2}$ (1.0 equiv). 2) $16 \mathrm{a}$ (1.0 equiv), $\mathrm{NEt}_{3}$ (2.0 equiv), $\mathrm{CCl}_{4}$ & 75 \\
\hline 10 & 1) $15 \mathrm{a}$ (1.2 equiv), $\mathrm{Br}_{2}$ (1.2 equiv), $\mathrm{CCl}_{4}$. 2) $16 \mathrm{a}$ (1.0 equiv), $\mathrm{NEt}_{3}$ (2.0 equiv), $\mathrm{CCl}_{4} / \mathrm{Et}_{2} \mathrm{O}$ (4:1) & 88 \\
\hline
\end{tabular}

aFirst reaction: $\mathrm{Br}_{2}\left(1 \mathrm{M}\right.$ in $\left.\mathrm{CCl}_{4}\right), 1 \mathrm{~h}, 0^{\circ} \mathrm{C}$. Second reaction: DMAP $\left(0.1\right.$ equiv), $2 \mathrm{~h}, 0{ }^{\circ} \mathrm{C} \rightarrow 25^{\circ} \mathrm{C}$. b $65 \%$ were obtained once for a small scale reaction.

the halogenated succinimides only NCS and NBS are able to convert the silane into a reactive species. However, the yields were low in all cases. Changing the bromination reagent to elemental bromine significantly improved the yields (Table 1, entries 4 and 5) [36]. Diethyl ether proved to be important as a solvent, the change to THF led to a total decomposition - most probably due to ring-opening reactions with bromosilanes [37]. Further, we investigated the influence of the amount of bromine on the reaction and concluded that stoichiometric quantities entirely fulfill the demands of the bromination (Table 1, entries 7 and 8). Finally, we found that the silyl bromide formation proceeded better in tetrachloromethane. However, to assure solubility of the glycals, small amounts of diethyl ether were added for the coupling step (Table 1, entries 8-10). In all cases, a very slow addition of bromine and bromosilane proved to be necessary to ensure optimal yields.

With optimized conditions in hand we explored the scope of the silyl ether coupling. Therefore, two different glycals and five different dialkynes were employed. In summary, seven different coupling products $\mathbf{1 4}$ were prepared baring alkynes with terminal H, TMS, $\mathrm{SiMe}_{2} \mathrm{Ph}, \mathrm{SiMe}_{2} \mathrm{Bn}$ and $\mathrm{Si}(\mathrm{iPr})_{2} \mathrm{OMe}$ groups (Scheme 5). The best results were obtained with TMSsubstituents. Although the $\mathrm{SiMe}_{2} \mathrm{Ph}$-substituted product was not synthesized under optimal reaction conditions the desired prod- uct was formed in high yield. In addition, terminal alkynes were tolerated in the reaction. Contrary, benzyl and methoxidesubstituted silanes $\mathbf{1 4 c}$ and $\mathbf{1 4 d}$ provided inferior yields.

With several domino precursors in hand we started the investigation of the domino-carbopalladation sequence. To our delight, it was possible to adjust the catalytic system that we developed for the synthesis of chromans and isochromans. Optimal reaction conditions comprise the use of $\mathrm{Pd}\left(\mathrm{PPh}_{3}\right)_{4}$ as a palladium source, $(t-\mathrm{Bu})_{3} \mathrm{PH} \cdot \mathrm{BF}_{4}$ (Fu's salt) [38] as an additional electronrich and sterically encumbered ligand and $\mathrm{HN}(\mathrm{iPr})_{2}$ as a base. As solvent a mixture consisting of $N, N$-dimethylformamide, acetonitrile and $N$-methylpyrrolidone (8:8:1) was used. The reaction was performed in a sealed vial at $120{ }^{\circ} \mathrm{C}$ under microwave irradiation for 3-5 h. The unusual combination of $\mathrm{Pd}\left(\mathrm{PPh}_{3}\right)_{4}$ and $(t-\mathrm{Bu})_{3} \mathrm{PH} \cdot \mathrm{BF}_{4}$ as an additional ligand proved beneficial for the transformation of long-chained dialkynes. The domino reaction proceeded smoothly and delivered the desired compounds as major products. Scheme 5 illustrates that all attached substituents at the terminal triple bond were tolerated. Even unsubstituted alkyne 14e and electron-deficient silane 14d furnished the product in high yields. TMS, $\mathrm{SiMe}_{2} \mathrm{Ph}$ and $\mathrm{Si}(\mathrm{iPr})_{2} \mathrm{OMe}$-substituted silanes delivered the best results with yields of up to $89 \%$. For the reaction mechanism we assume that the palladium $(0)$ inserts into the $\mathrm{C}\left(\mathrm{sp}^{2}\right)-\mathrm{Br}$ bond to form a 


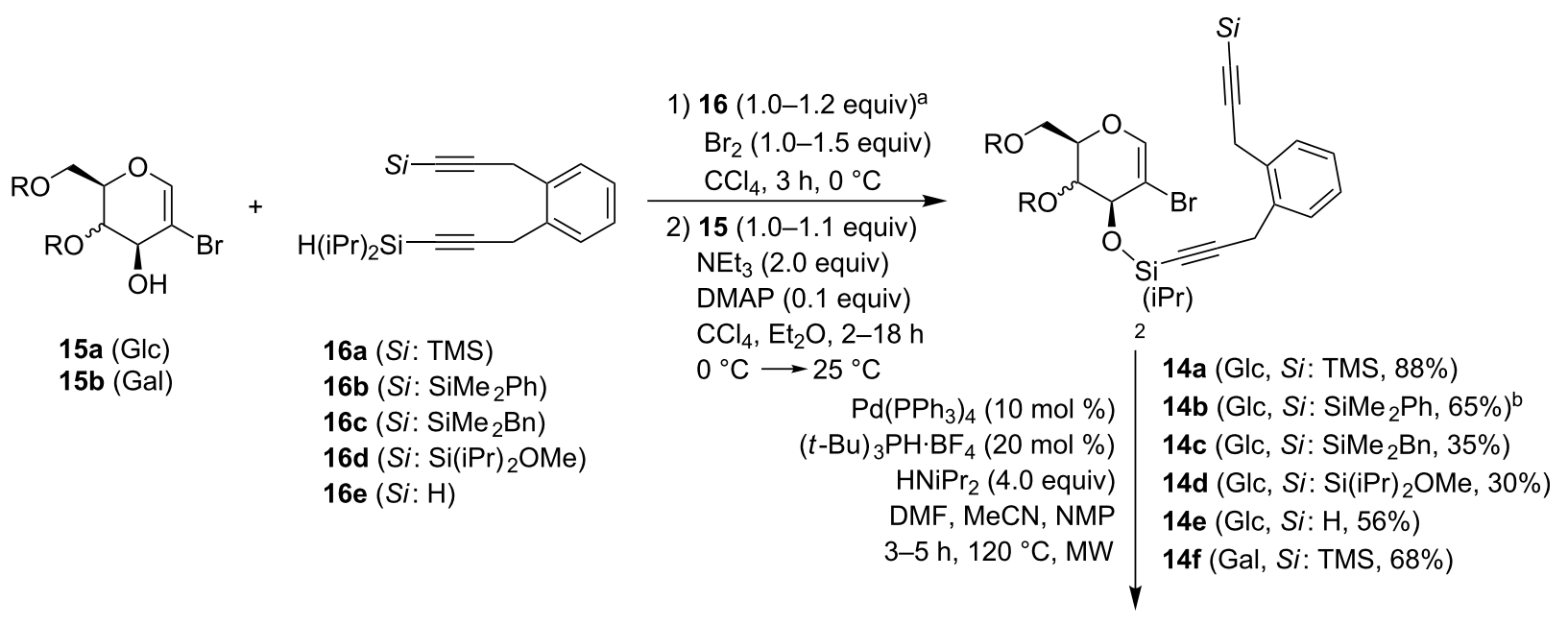

13a (Glc, Si: TMS, 81\%)

13b (Glc, Si: $\mathrm{SiMe}_{2} \mathrm{Ph}, 89 \%$ )

13c (Glc, Si: $\left.\mathrm{SiMe}_{2} \mathrm{Bn}, 70 \%\right)$

13d (Glc, Si: Si(iPr) $\left.{ }_{2} \mathrm{OMe}, 86 \%\right)$

13e (Glc, Si: H, 67\%)

$13 f$ (Gal, Si: TMS, 74\%)

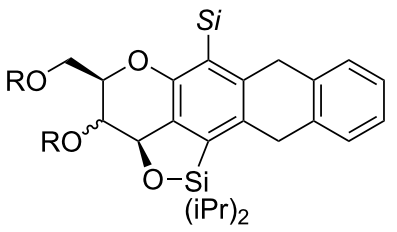

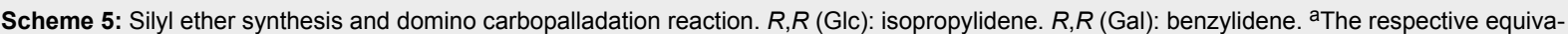
lents of alkynes 16, glycals 15 and bromine as well as reaction times are given in the Experimental. ${ }^{\text {b }}$ The reaction was performed according to entry 5 of Table 1.

Pd(II) species. A sequence of two carbopalladation reactions form a triene system which is able to cyclize by a Heck-type reaction, a $6 \pi$-electrocyclization [39] or a direct $\mathrm{CH}$-activation to the respective anthracycline precursor 13. The design of the dialkyne provides a simultaneous formation of the linear ring system. All four cycles were annulated in a single step, in which the $\mathrm{B}$ and $\mathrm{C}$-ring were formed as a consequence of the reaction cascade.

\section{Derivatization to anthracycline derivatives}

The derivatization of the domino products turned out to be challenging. Utilization of a fluoride source (e.g. tetrabutylammonium fluoride or tetramethylammonium fluoride) and 13a lead to total decomposition of the starting materials. Application of Tamao-Fleming-like oxidative procedures provided only the mono-oxidized products in trace amounts [40-42]. The oxidation of phenyl-substituted silanes to respective phenols is difficult $[43,44]$. However, literature precedence revealed that benzyl-substituted silane 13c or electron-deficient silane 13d $[43,45]$ should be more promising candidates. But none of these domino products $\mathbf{1 3 b}-\mathbf{1 3 f}$ provided better results in a Tamao-Fleming reaction. When oxidizing reaction conditions were applied to silane $\mathbf{1 3 b}$, only desilylation of the cyclic silyl ether occurred. Interestingly, benzylsilane $\mathbf{1 3 c}$ afforded the globally desilylated product in $90 \%$ yield under oxidative reac- tion conditions $\left(\mathrm{KHCO}_{3}, \mathrm{H}_{2} \mathrm{O}_{2}, \mathrm{KF}\right.$ in THF and $\left.\mathrm{MeOH}\right)$, i.e., both silyl ether and terminal silane were cleaved. However, it was not possible to utilize this procedure for compound 13a. Under these conditions, the silyl ether was cleaved without touching the trimethylsilyl moiety. Another approach of selective silyl ether cleavage was employed by utilization of $\mathrm{Cs}_{2} \mathrm{CO}_{3}$ (5.0 equiv) in methanol at $100{ }^{\circ} \mathrm{C}$.

Hydrolysis of the respective domino products 13a and 13f with in situ formed $\mathrm{HCl}$ in methanol furnished the diols 26a and 26b under loss of the terminal TMS group [46]. Opening of the silyl ether moiety was accomplished by treatment with TBAF in quantitative yield and gained access to the natural substitution pattern of the carbohydrate backbone. It was not possible to open the silyl ether moiety of $\mathbf{2 6}$ by the utilization of $\mathrm{Cs}_{2} \mathrm{CO}_{3}$ in methanol starting from $\mathbf{1 3}$ as described before. To install the anthraquinone moiety it was necessary to reprotect the alcohol functionalities. It has proven challenging to install the TBS protecting group at the substrates, particular for the galactosederived derivatives $\mathbf{1 2 b}$ which could be obtained in only poor yield [47-49]. For 27 a the $\mathrm{FeCl}_{3}$-catalyzed benzylic oxidation proceeded smoothly with yields of up to $70 \%$ [50]. A final hydrolysis with hydrochloric acid afforded the desired carbohydrate-based anthracycline derivatives $\mathbf{1 1}$ in good yield (Scheme 6). 


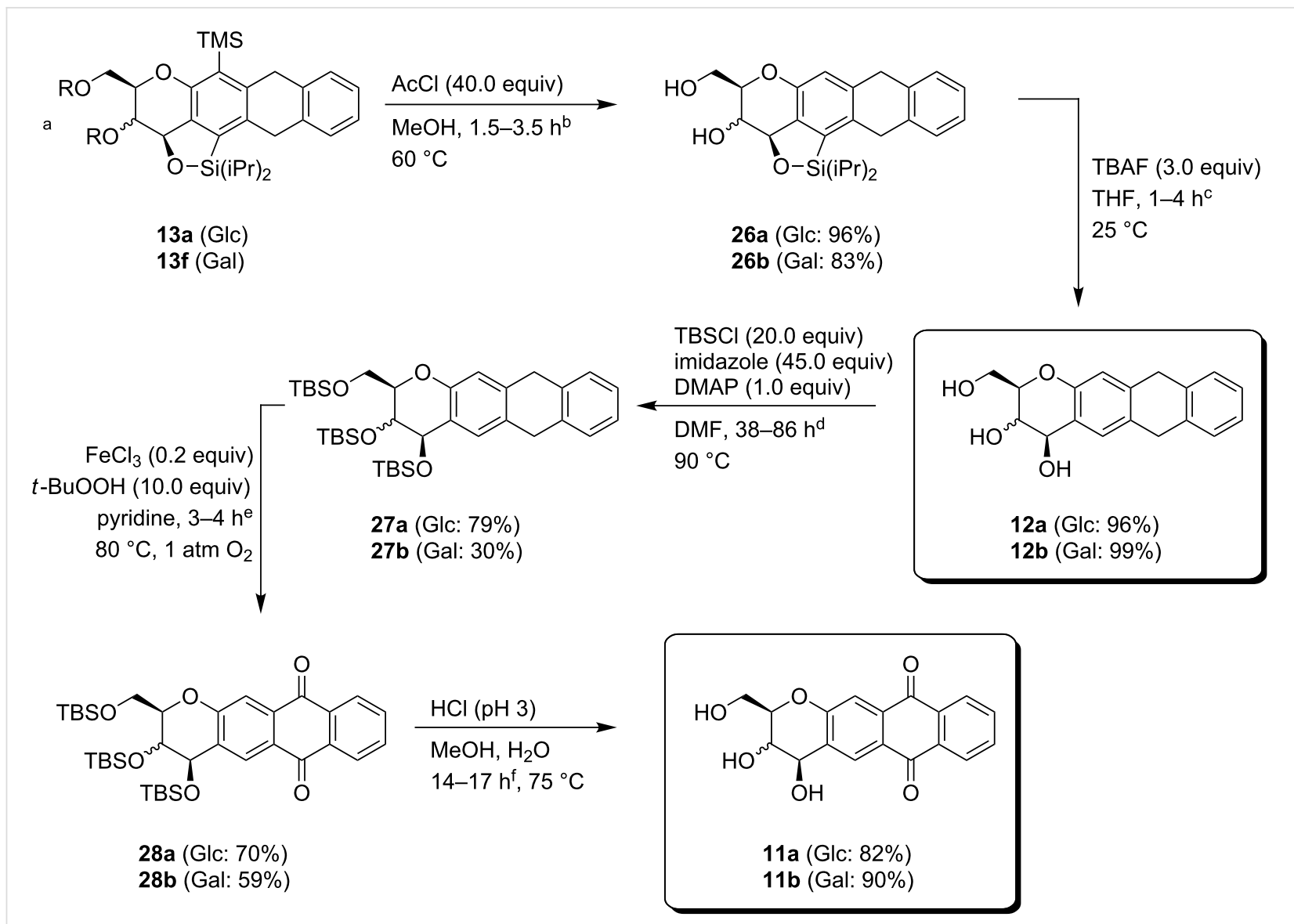

Scheme 6: Derivatisation of anthracycline derivatives. ${ }^{a} R, R(\mathrm{Glc})$ : isopropylidene. $R, R(\mathrm{Gal})$ : benzylidene. Reactions times: ${ }^{1} 1.5 \mathrm{~h}$ (Glc), $3.5 \mathrm{~h}(\mathrm{Gal})$.

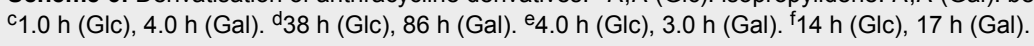

\section{Conclusion}

In conclusion, we have developed a concise and robust approach to anthracycline aglycone derivatives. Starting materials were bromoglycals and benzene moieties with two propynyl residues. The first key step is the union of these moieties by a silyl ether linkage. In a second key step the tetracyclic anthracycline scaffold is formed by a domino carbopalladation sequence generating both, the B and the C-ring of the system in a single step. Further derivatisation included the cleavage of the silyl ether and two-fold benzylic oxidation to the quinone moiety. We believe that these natural product mimics might be of interest as useful candidates for drug discovery research.

\section{Supporting Information}

\section{Supporting Information File 1}

Experimental details and analytical data of all new compounds as well as their ${ }^{1} \mathrm{H}$ and ${ }^{13} \mathrm{C}$ NMR spectra. [http://www.beilstein-journals.org/bjoc/content/ supplementary/1860-5397-9-258-S1.pdf]

\section{Acknowledgements}

We are grateful to the Deutsche Forschungsgemeinschaft (DFG) and the Fonds der Chemischen Industrie (FCI) for financial support (Emmy Noether and Heisenberg Fellowships as well as Dozentenstipendium to D.B.W.). M.L. thanks the State of Lower Saxony for his Ph.D. Lichtenberg Fellowship within the CaSuS (Catalysis for Sustainable Synthesis) program. We thank Prof. Dr. Lutz F. Tietze (University of Göttingen) for helpful discussions and generous support of our work.

\section{References}

1. Laatsch, H.; Fotso, S. Top. Curr. Chem. 2008, 282, 3-74. doi:10.1007/128_2008_5

2. Brockmann, H. Fortschr. Chem. Org. Naturst. 1963, 21, 121-182.

3. Grynkiewicz, G.; Wieslaw, S. Top. Curr. Chem. 2008, 282, 249-284. doi:10.1007/128_2007_7

4. Leng, F.; Savkur, R.; Fokt, I.; Przewloka, T.; Priebe, W.; Chaires, J. B. J. Am. Chem. Soc. 1996, 118, 4731-4738. doi:10.1021/ja9542606

5. Chaires, J. B.; Satyanarayana, S.; Suh, D.; Fokt, I.; Przewloka, T.; Priebe, W. Biochemistry 1996, 35, 2047-2053. doi:10.1021/bi952812r

6. Menna, P.; Salvatorelli, E.; Gianni, L.; Minotti, G. Top. Curr. Chem. 2008, 283, 21-44. doi:10.1007/128_2007_11 
7. Minotti, G.; Menna, P.; Salvatorelli, E.; Cairo, G.; Gianni, L. Pharmacol. Rev. 2004, 56, 185-229. doi:10.1124/pr.56.2.6

8. Cortés-Funes, H.; Coronado, C. Cardiovasc. Toxicol. 2007, 7, 56-60. doi:10.1007/s12012-007-0015-3

9. Filippini, S.; Lomovskaya, N.; Fonstein, L.; Colombo, A. L.; Hutchinson, C. R.; Otten, S. L.; Breme, U. Process for preparing doxorubicin. U.S. Patent 6,210,930 B1, April 3, 2001.

10. Vogel, P. Top. Curr. Chem. 2008, 282, 187-214. doi:10.1007/128_2007_148

11. Gupta, R. C.; Harland, P. A.; Stoodley, R. J. J. Chem. Soc., Chem. Commun. 1983, 754-756. doi:10.1039/C39830000754

12. Tamariz, J.; Vogel, P. Tetrahedron 1984, 40, 4549-4560. doi:10.1016/S0040-4020(01)91514-5

13. Carrupt, P.-A.; Vogel, P. Tetrahedron Lett. 1979, 20, 4533-4536. doi:10.1016/S0040-4039(01)86642-9

14. Hansen, D. W., Jr.; Pappo, R.; Garland, R. B. J. Org. Chem. 1988, 53, 4244-4253. doi:10.1021/jo00253a016

15. Rodríguez, D.; Castedo, L.; Domínguez, D.; Saá, C. Org. Lett. 2003, 5, 3119-3121. doi:10.1021/ol035168e

16. Kesenheimer, C.; Kalogerakis, A.; Meißner, A.; Groth, U. Chem.-Eur. J. 2010, 16, 8805-8821. doi:10.1002/chem.201000804

17. Leibeling, M.; Koester, D. C.; Pawliczek, M.; Schild, S. C.; Werz, D. B. Nat. Chem. Biol. 2010, 6, 199-201. doi:10.1038/nchembio.302

18. Leibeling, M.; Koester, D. C.; Pawliczek, M.; Kratzert, D.; Dittrich, B.; Werz, D. B. Bioorg. Med. Chem. 2010, 18, 3656-3667. doi:10.1016/j.bmc.2010.03.004

19. Leibeling, M.; Milde, B.; Kratzert, D.; Stalke, D.; Werz, D. B. Chem.-Eur. J. 2011, 17, 9888-9892. doi:10.1002/chem.201101917

20. Leibeling, M.; Werz, D. B. Chem.-Eur. J. 2012, 18, 6138-6141. doi:10.1002/chem.201200175

21. Leibeling, M.; Pawliczek, M.; Kratzert, D.; Stalke, D.; Werz, D. B. Org. Lett. 2012, 14, 346-349. doi:10.1021/ol2030923

22. Tietze, L.-F.; Brasche, G.; Gericke, K. M. Domino Reactions in Organic Synthesis; Wiley-VCH: Weinheim, Germany, 2006. doi:10.1002/9783527609925

23. Tietze, L. F. Chem. Rev. 1996, 96, 115-136. doi:10.1021/cr950027e

24. Nicolaou, K. C.; Edmonds, D. J.; Bulger, P. G. Angew. Chem., Int. Ed. 2006, 45, 7134-7186. doi:10.1002/anie.200601872

25. Sugihara, T.; Copéret, C.; Owczarczyk, Z.; Harring, L. S.; Negishi, E.-i. J. Am. Chem. Soc. 1994, 116, 7923-7924. doi:10.1021/ja00096a070

26. Negishi, E.-i.; Copéret, C.; Ma, S.; Liou, S.-Y.; Liu, F. Chem. Rev. 1996, 96, 365-394. doi:10.1021/cr950020x

27. Tietze, L. F.; Sommer, K. M.; Zinngrebe, J.; Stecker, F. Angew. Chem., Int. Ed. 2005, 44, 257-259. doi:10.1002/anie.200461629

28. Jay-Smith, M.; Furkert, D. P.; Sperry, J.; Brimble, M. A. Synlett 2011, 1395-1398. doi:10.1055/s-0030-1260564

29. Aïssa, C.; Fürstner, A. J. Am. Chem. Soc. 2007, 129, 14836-14837. doi:10.1021/ja0746316

30. Chan, J.; Jamison, T. F. J. Am. Chem. Soc. 2003, 125, 11514-11515. doi:10.1021/ja0373925

31. Takahashi, T.; Li, S.; Huang, W.; Kong, F.; Nakajima, K.; Shen, B.; Ohe, T.; Kanno, K.-i. J. Org. Chem. 2006, 71, 7967-7977. doi:10.1021/jo060923y

32. Krohn, K.; Micheel, J. Tetrahedron 1998, 54, 4827-4838. doi:10.1016/S0040-4020(98)00188-4

33. Imahori, T.; Ojima, H.; Yoshimura, Y.; Takahata, H. Chem.-Eur. J. 2008, 14, 10762-10771. doi:10.1002/chem.200801439
34. Sharma, P.; Moses, J. E. Org. Lett. 2010, 12, 2860-2863. doi:10.1021/ol100968t

35. Petit, M.; Chouraqui, G.; Aubert, C.; Malacria, M. Org. Lett. 2003, 5, 2037-2040. doi:10.1021/ol034207j

36. Pichaandi, K. R.; Mague, J. T.; Fink, M. J. J. Organomet. Chem. 2011, 696, 1957-1963. doi:10.1016/j.jorganchem.2010.10.043

37. Voronkov, M. G.; Puzanova, V. E.; Pavlov, S. F.; Dubinskaya, É. I. Russ. Chem. Bull. 1975, 24, 377-378. doi:10.1007/BF00925793

38. Netherton, M. N.; Fu, G. C. Org. Lett. 2001, 3, 4295-4298. doi:10.1021/ol016971g

39. Beaudry, C. M.; Trauner, D. Org. Lett. 2002, 4, 2221-2224. doi:10.1021/ol026069o

40. Tamao, K.; Akita, M.; Kumada, M. J. Organomet. Chem. 1983, 254, 13-22. doi:10.1016/0022-328X(83)85112-2

41. Tamao, K.; Ishida, N.; Kumada, M. J. Org. Chem. 1983, 48, 2120-2122. doi:10.1021/jo00160a046

42. Fleming, I.; Henning, R.; Plaut, H. J. Chem. Soc., Chem. Commun. 1984, 29-31. doi:10.1039/C39840000029

43. Ihara, H.; Suginome, M. J. Am. Chem. Soc. 2009, 131, 7502-7503. doi:10.1021/ja902314v

44. Sunderhaus, J. D.; Lam, H.; Dudley, G. B. Org. Lett. 2003, 5, 4571-4573. doi:10.1021/ol035695y

45. Goh, S. S.; Baars, H.; Gockel, B.; Anderson, E. A. Org. Lett. 2012, 14, 6278-6281. doi:10.1021/ol303041j

46. Li, S.; Zhou, L.; Song, Z.; Bao, F.; Kanno, K.-i.; Takahashi, T. Heterocycles 2007, 73, 519-536. doi:10.3987/COM-07-S(U)28

47. Koester, D. C.; Leibeling, M.; Neufeld, R.; Werz, D. B. Org. Lett. 2010, 12, 3934-3937. doi:10.1021/ol101625p

48. Koester, D. C.; Werz, D. B. Beilstein J. Org. Chem. 2012, 8, 675-682. doi:10.3762/bjoc.8.75

49. Koester, D. C.; Kriemen, E.; Werz, D. B. Angew. Chem., Int. Ed. 2013, 52, 2985-2989. doi:10.1002/anie.201209697

50. Nakanishi, M.; Bolm, C. Adv. Synth. Catal. 2007, 349, 861-864. doi:10.1002/adsc.200600553

\section{License and Terms}

This is an Open Access article under the terms of the Creative Commons Attribution License (http://creativecommons.org/licenses/by/2.0), which permits unrestricted use, distribution, and reproduction in any medium, provided the original work is properly cited.

The license is subject to the Beilstein Journal of Organic Chemistry terms and conditions:

(http://www.beilstein-journals.org/bjoc)

The definitive version of this article is the electronic one which can be found at: doi:10.3762/bjoc. 9.258 